Article Type: Research Paper

\title{
The Association of Tax Aggressiveness on Accrual and Real Earnings Management
}

\author{
Antonius Herusetya ${ }^{1 *}$ and Cyrilla Stefani ${ }^{2}$
}

\begin{abstract}
:
Research aims: This study examines the association of tax aggressiveness and earnings management practices using the accrual and real transaction-based earnings management.
\end{abstract}

AFFILIATION:

1, 2 Department of Accounting, Faculty of Economic and Business, Universitas Pelita Harapan, Tangerang, Indonesia.

Design/Methodology/Approach: We use a purposive sampling method from the manufacturing industry listed on the Indonesia Stock Exchange (IDX) from 2013 to 2017 and obtain a final sample of 500 firm-year observations. Data analysis is conducted using multiple regression models and Stata software.

*CORRESPONDENCE:

antonius.herusetya@uph.edu

THIS ARTICLE IS AVAILABLE IN:

http://journal.umy.ac.id/index.php/ai

DOI: 10.18196/jai.2103158

\section{CITATION:}

Herusetya, A. \& Stefani, C. (2020). The Association of Tax Aggressiveness on Accrual and Real Earnings Management. Journal of Accounting and Investment, 21(3), 434-451.

\section{ARTICLE HISTORY}

\section{Received:}

$20 \mathrm{Jul} 2020$

Reviewed:

21 Jul 2020

Revised:

3 Aug 2020

Accepted:

Research findings: Our study finds strong evidence that tax aggressiveness has a positive association with accrual earnings management. Our study also finds contrary evidence that tax aggressiveness has a negative association with real transaction activities at the aggregate level. Further testing found a negative relationship between tax aggressiveness and real transactions at the individual level, i.e., sales manipulation and reduction in discretionary expenses, consistent with our main findings.

Theoretical contribution/Originality: Our study extends previous studies on the association of tax aggressiveness using tax shelter prediction model, and aggressive financial reporting using accrual and real transaction-based earnings management. We use tax prediction model in this study as the highest level of tax aggressiveness which is rarely performed in the case of Indonesia.

Practitioner/Policy implication: The results of this study provide the implication that to achieve the objectives of aggressive tax reporting and aggressive financial reporting in the same reporting period, managers use accrual and real transaction-based earnings management tools as complementary or substitution to each other.

Research limitation/Implication: This study uses Wilson's (2009) tax shelter prediction model as a proxy of the highest level of tax aggressiveness.

Keywords: Tax Aggressiveness; Tax Shelter; Earnings Management; Real Transaction

\section{Introduction}

Tax avoidance has become interesting discussions to study and how its economic consequences on the earnings quality of corporations.

Shackelford and Shevlin (2001) have reviewed prior studies on how managers make trade-offs between financial reporting and tax reporting decisions. Specifically, managers can report high earnings for the benefit of shareholders, but at the same time must bear high tax costs. On the other hand, managers report lower taxable income, but bear financial reporting costs for reporting lower earnings to shareholders (Frank, Lynch, \& Rego, 2009). 


\author{
Herusetya \& Stefani \\ The Association of Tax Aggressiveness on Accrual and Real Earnings Management
}

In reality, managers do not always trade-off between tax and financial reporting decisions. It was seen on the widening gap between earnings reported to the tax authorities and financial statement earnings (Hanlon, Laplante, \& Shevlin, 2005; Desai, 2002; Shevlin, 2002). The significant differences between tax rules and applicable financial reporting standards can allow managers to report higher accounting earnings and smaller taxable income in the same period (Kim \& Park, 2014; Frank et al., 2009). The companies that carry out tax aggressiveness as part of their tax planning strategy are suspected of having lower earnings quality, reporting financial misstatements, and performing restatement (Zang, Goh, Lim, \& Shevlin, 2013).

Tax aggressiveness is "... as downward manipulation of taxable income through tax planning that may or may not be considered fraudulent tax evasion" (Frank et al., 2009, p. 468). One of the tax aggressiveness mechanisms is to use tax shelters (Kim, Li, \& Zhang, 2011; Wilson, 2009; Rego \& Wilson, 2012; Frank et al., 2009). Wilson (2009) found evidence that the higher the value of tax shelters, the more consistent the managers engage in aggressive tax avoidance. So examining tax shelters is the main issue for the tax authority and investors to detect aggressive tax positions in the public companies (Hanlon \& Heitzman, 2010).

Prior studies that examine the association between tax aggressiveness and financial reporting aggressiveness directly are rare, and the results are mixed (e.g., Frank et al., 2009; Lennox, Lisowsky, \& Pittman, 2013). Frank et al. (2009), for example found strong evidence that aggressive financial reporting is positively associated with aggressive tax reporting using tax shelter activities and vice versa. In other words, companies involved in tax shelter activities are also involved in aggressive financial reporting through earnings manipulation and hiding company-specific information using tax planning (Frank et al., 2009; Kim et al., 2011). In contrast, Lennox et al. (2013) found evidence contrary from Frank et al. (2009), that public listed companies in the United States that involved in tax aggressiveness did not engage in the fraudulent financial statements identified through AAERs (Accounting and Auditing Enforcement Releases) of the SEC. The findings of Lennox et al. (2013) reject evidence (e.g., Frank et al., 2009) and the argument (e.g., Desai \& Dharmapala, 2006) that companies that engage in aggressive tax activities have an aggressive financial statement.

Consistent with the agency theory, researchers have previously argued that complex tax avoidance activities can facilitate managers opportunistically, such as related party transactions, other resource-diverting activities, and earnings manipulation (Kim et al., 2011; Frank et al., 2009; Geraldina, 2013; Desai \& Dharmapala, 2009). They suggest that tax aggressiveness is a risky tax position activity and contains costs for companies and managers; therefore, managers must have incentives when dealing with tax aggressiveness to provide net benefits for companies and shareholders (Dyreng, Hanlon, \& Maydew, 2019; Rego \& Wilson, 2009).

The most commonly used technique for managers to manipulate earnings is using accrual and real transaction-based earnings management tools (Kim \& Park, 2014; Cohen \& Zarowin, 2010; Badertscher, Phillips, Pincus, \& Rego, 2009; Zang, 2012). To 


\section{Herusetya \& Stefani \\ The Association of Tax Aggressiveness on Accrual and Real Earnings Management}

achieve aggressive tax reporting goals, managers can use accrual-based earnings management, for example, valuation allowances, tax contingency reserves and accrued tax estimates (Hanlon \& Heitzman, 2010; Frank \& Rego, 2006; Dhaliwal, Gleason, \& Mills, 2004). However, previous studies also found that managers use real earnings management and accrual-based earnings management as substitutes for each other to achieve earnings targets (e.g., Chan, Chen, \& Chen, \& Yu, 2019; Zang, 2012; Cohen \& Zarowin, 2010; Graham, Harvey, \& Rajgopal, 2005; Kothari, Mizik, \& Roychowdhury, 2016).

Our study investigates and extends previous studies on the relationship of tax aggressiveness and aggressive financial reporting using earnings management tools as a measure of earnings quality, especially in Indonesia (e.g., Frank et al., 2009; Geraldina, 2013; Surahman \& Firmansyah, 2017). Frank et al. (2009) found evidence that both tax aggressiveness and financial reporting aggressiveness were positively related, consistent with Kim et al. (2011, p. 642), which states that "tax avoidance and managerial diversion can be complimentary." Two other studies in Indonesia found that real transaction activities through abnormal production costs increase the likelihood of companies engaging in an aggressive tax shelter, whereas abnormal CFO and abnormal discretionary expenses as the other real transaction activities have mixed results against the aggressive tax shelter (Surahman \& Firmansyah, 2017; Geraldina, 2013).

Our study is different from previous studies on some points. First, our study is different from Surahman and Firmansyah (2017), and Geraldina (2013), because they examine the effect of earnings management on the tax aggressiveness while our study is the opposite. The results of their studies differ from one another. For example, Surahman and Firmansyah (2017) found that accrual earnings management had a positive effect on tax aggressiveness, whereas Geraldina (2013) found that companies tended to use accrual earnings management to reduce tax shelter activities. Surahman and Firmansyah (2017) found evidence that real transaction management through abnormal CFO has a negative association with tax aggressiveness, and abnormal discretionary expense and abnormal production have a positive effect on tax aggressiveness. In contrast, Geraldina (2013) found that abnormal CFO and abnormal production had a positive effect on tax aggressiveness, respectively. Frank et al. (2009) found that tax aggressiveness can be associated with aggressive financial reporting measured by accrual-based earnings management, and vice versa. In other words, earnings management can influence companies to engage in aggressive tax shelter activities. Conversely, tax aggressiveness can also encourage opportunistic managers to get involved in earnings management behavior (Kim et al., 2011; Wilson, 2009). This study is important due to the academic and practical implications. Second, real transaction earnings management conducted by the two previous studies are each measured using an individual level of real transactions, consisting of sales manipulation, overproduction, and reducing discretionary expense activities. While previous studies suggest that managers carry out real transaction manipulation by combining these individual measures (Roychowdhury, 2006; Chi, Lisic, \& Pevzner, 2011; Cohen \& Zarowin, 2010). Our study examines the manipulation of real transactions at both the aggregate and individual levels. Third, our study measures tax aggressiveness using Wilson's (2009) tax shelter prediction model 


\author{
Herusetya \& Stefani \\ The Association of Tax Aggressiveness on Accrual and Real Earnings Management
}

implemented by Kim et al. (2011), and as far as the author's knowledge, the model has never been tested in Indonesia. We test this prediction model as the highest level of tax aggressiveness which is rarely performed (Lisowsky, Robinson, \& Schmidt, 2013). Previous studies in Indonesia generally use proxies such as Book Tax Differences (BTD) (e.g., Octavia \& Martani, 2013), Effective Tax Rates (ETR) (e.g., Hidayati \& Diyanty, 2018; Sandy \& Lukviarman, 2015; Octavia \& Martani, 2013), and Cash ETR (e.g., Maraya \& Yendrawati, 2016; Astutik \& Venusita, 2020).

\title{
Literature Review and Hypotheses Development
}

\section{Tax Aggressiveness and Accrual Earnings Management}

Aggressive tax reporting is defined as an attempt to manipulate tax payable through tax planning that can contain an element of tax evasion (Frank et al. 2009). Hanlon and Heitzman (2010, p. 137) stated "If tax avoidance represents a continuum of tax planning strategies where something like municipal bond investments are at one end, then terms such as 'non-compliance', 'evasion', 'aggressiveness', and 'sheltering' would be closer to the other end of the continuum." Consistent with Hanlon and Heitzman (2010), tax avoidance in our study is more inclined to uncertain conditions, namely aggressiveness activities and tax shelters. Tax aggressiveness strategies involve uncertainty and contain costs for companies and managers (Dyreng et al., 2019; Rego \& Wilson, 2009). Therefore managers must have incentives to deal with these risky activities of tax avoidance (Rego \& Wilson, 2012). Previous studies have also documented that managers do not have to trade-off between the decisions of aggressive tax reporting and aggressive financial reporting (Frank et al., 2009). In other words, managers can achieve aggressive tax reporting and aggressive financial reporting goals in the same period.

Corporate tax avoidance requires manipulative actions that can be related to relatedparty transactions, earnings manipulation, and other diverting activities carried out in the interests of managers (Kim et al., 2011; Desai \& Dharmapala, 2006). Management efforts aimed at manipulating earnings by increasing earnings are one form of aggressive financial reporting (Frank et al., 2009). Earnings manipulation can be done by various mechanisms, such as accrual-based earnings management and real transaction tools (e.g., Graham et al., 2005; Kim \& Park, 2014; Cohen \& Zarowin, 2010). Previous studies found evidence that aggressive tax reporting is positively related to aggressive financial reporting. Frank et al. (2009), for example, found that aggressive tax reporting is positively related to discretionary accruals as a proxy of aggressive financial reporting. Managers use accrual-based earnings management, for example, tax contingency reserves, valuation allowances, and estimated tax accrued to achieve tax reporting goals (Dhaliwal et al., 2004; Frank \& Rego, 2006; Hanlon \& Heitzman, 2010).

Based on the arguments above, the hypothesis to be tested is stated as follows:

$\boldsymbol{H}_{1}$ : Tax aggressiveness has a positive effect on accrual earnings management. 


\author{
Herusetya \& Stefani \\ The Association of Tax Aggressiveness on Accrual and Real Earnings Management
}

\title{
Tax Aggressiveness and Real Transaction Earnings Management
}

Real earnings management is a manipulation of real activities through deviations from the normal operational practices that are motivated by managers' desire to provide incorrect information to stakeholders that the objectives of financial reporting have been met as they should. This deviation does not always contribute to the company's value, although it allows managers to achieve earnings targets (Roychowdhury, 2006).

Previous studies have also found that managers can conduct aggressive financial reporting using real transaction activities (e.g., Kim \& Park, 2014; Roychowdhury, 2006), and make substitutions for accrual earnings management tools with the real transactions to achieve earnings targets (Chan et al., 2015; Zang, 2012; Geraldina, 2015; Graham et al., 2005). Managers choose to use a combination of accrual and real earnings management based on needs, such as consideration of time, costs, supervision from regulators and investors, flexible accounting practices, the company's financial condition in order to achieve its earnings target (Chan et al., 2015; Zang, 2012). Also, managers tend to choose real earnings management as a safer method because it is more difficult to be detected by auditors, regulators, and others (Kim \& Park, 2014; Graham et al., 2005; Cohen \& Zarowin, 2010).

Based on the arguments above, the hypothesis to be tested is stated as follows:

$\boldsymbol{H}_{2}$ : Tax aggressiveness has a positive effect on real earnings management.

\section{Research Method}

\section{Population and Sample Selection}

This study's population is public companies from manufacturing industries listed on the Indonesia Stock Exchange, consisting of the mining industry, primary industry and chemicals, and miscellaneous industry. We choose a sample from the manufacturing industry population because one of the mechanisms of real transaction activities at the operational level is by producing over-production. The sample selection uses a purposive sampling method with the following criteria: 1 . Manufacturing companies have been listed on the Indonesia Stock Exchange before 2013; 2. Listed manufacturing companies exist throughout the year 2013-2017; 3 Annual reports, audited financial statements, and items needed for computing tax shelter for the year ended December 31 are available during 2012-2017; 4. Financial statements are published using the currency of Rupiah; Based on the sample selection above, we obtain a final sample of 500 firm-year observations, as seen in Table 1. 


\section{Herusetya \& Stefani}

The Association of Tax Aggressiveness on Accrual and Real Earnings Management

Table 1 Sample Selection

\begin{tabular}{lc}
\multicolumn{1}{c}{ Description } & $\begin{array}{c}\text { Number of } \\
\text { observations }\end{array}$ \\
\hline $\begin{array}{l}\text { Firm-year observations in primary and chemical industries, various industries, } \\
\text { and consumer goods industries for the year 2013-2017 } \\
\text { Less: }\end{array}$ & 144 \\
Number of firms with missing data during 2012-2017 & $(11)$ \\
Number of firms with unaudited financial statements during 2012-2017 & $(31)$ \\
$\begin{array}{l}\text { Number of firms with foreign currencies other than Rupiah stated in the } \\
\text { financial statements during 2012-2017 }\end{array}$ & 100 \\
$\begin{array}{l}\text { Number of final samples during 2013-2017 } \\
\text { Number of final firm-years observations }\end{array}$ & 500 \\
\hline $\begin{array}{l}\text { All data are obtained from 2013 - 2017, except for prior year going concern opinion (PRIORGCO) and } \\
\text { change in return on assets ( } \triangle \mathrm{ROA} \text { ) from 2012. }\end{array}$ \\
\hline
\end{tabular}

\section{Research Empirical Models}

Accrual Earnings Management (ABSDAC) as Dependent Variable

To test the first hypothesis (H1), we use the empirical model as follows:

$$
\begin{aligned}
\text { ABSDAC }_{i t}= & \beta_{0}+\beta_{1} \text { TAXAGG }_{i t}+\beta_{2} \text { ROA }_{i t}+\beta_{3} \Delta \text { ROA }_{i t}+\beta_{4} \text { SIZE }_{i t}+\beta_{5} \text { LEV }_{i t}+\beta_{6} G_{R O W T H} \\
& +\beta_{7} \text { AGE }_{i t}+\beta_{8} \text { LOSS }_{i t}+\beta_{9} \text { PRIORGCO }_{i t-1}+\beta_{10} \text { REM }_{i t}+\delta_{x} \text { INDUSTRY } \sigma_{y} \text { YEAR } \\
& +e_{i t}
\end{aligned}
$$

Based on the research model in Equation (1), the coefficient $\beta 1$ of the main variable tax aggressiveness (TAXAGG) is predicted to have a positive and significant association with earnings accrual management (ABSDAC). Following Rego and Wilson (2012), discretionary accruals are calculated using performance-adjusted modified Jones's (1991) model that has been modified by Kothari, Leone, \& Wasley (2005). Accrual discretionary is calculated using Equation (2) as follows:

$\mathrm{TACCR}_{\mathrm{it}} / \mathrm{TA}_{\mathrm{it}-1}=\theta_{0}+\theta_{1} 1 / \mathrm{TA}_{\mathrm{it}-1}+\theta_{2} \mathrm{SSA} / \mathrm{TA}_{\mathrm{it}-1}+\theta_{3}$ SPPENT $/ \mathrm{TA}_{\mathrm{it}-1}+\theta_{4} \mathrm{ROA}_{\mathrm{it}}+\mathrm{e}_{\mathrm{it}}$

The accrual discretionary (DAC) of Equation (2) is obtained from the total actual accrual (TACCR) deducted by the estimated value of TACCR from the Equation (2), or DAC= TACCR - NDAC. ABSDAC is the absolute value of the DAC, considering the motives of accrual earnings management can be done with the increasing or decreasing discretionary accruals that gives consequences to the lower earnings quality (Gul, Fung, \& Jaggi, 2009). See Table 2 for complete variable definitions of Equation (1) and (2).

Real Earnings Management (REM) as Dependent Variable

To test the second hypothesis (H2), we use Equation (3) as follows:

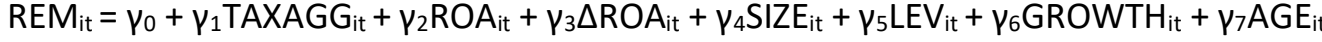

$$
\begin{aligned}
& +\gamma_{8} \text { LOSS }_{i \mathrm{t}}+\gamma_{9} \text { PRIORGCO }_{\mathrm{it}-1}+\gamma_{10} \text { ABSDAC }_{i \mathrm{t}}+\delta_{\mathrm{x}} \text { INDUSTRY }+\sigma_{\mathrm{y}} \text { YEAR }+\mathrm{e}_{\mathrm{it}}
\end{aligned}
$$




\section{Herusetya \& Stefani}

The Association of Tax Aggressiveness on Accrual and Real Earnings Management

Based on the second empirical model in Equation (3), the coefficient $\gamma 1$ of the main variable tax aggressiveness (TAXAGG) is predicted to be positive and significant toward the real earnings management on an aggregate level (REM).

Table 2 Definition of Variables

\begin{tabular}{|c|c|c|}
\hline Variables & & Definition \\
\hline \multicolumn{3}{|c|}{ Equation (1) and (3) } \\
\hline ABSDAC & $=$ & $\begin{array}{l}\text { The absolute value of abnormal discretionary accruals. Following Rego } \\
\text { and Wilson (2012), discretionary accruals are calculated using } \\
\text { performance-adjusted modified Jones's (1991) model that has been } \\
\text { modified by Kothari et al. (2005). }\end{array}$ \\
\hline REM & $=$ & $\begin{array}{l}\text { Real transaction earnings management. Following Kim and Park (2014) } \\
\text { and Roychowdhury (2006), REM is the sum of the standardized value } \\
\text { of real transaction activities at individual levels, i.e., abnormal CFO } \\
\text { (ABCFO), abnormal production (ABPROD), and abnormal discretionary } \\
\text { expense (ABDISEXP) as calculated in Equation (4), (5), (6), respectively. }\end{array}$ \\
\hline TAXAGG & $=$ & $\begin{array}{l}\text { Tax aggressiveness. The value of tax aggressiveness are obtained from } \\
\text { the value of Wilson's (2009) tax shelter prediction model. }\end{array}$ \\
\hline SIZE & $=$ & Natural logarithm of total assets \\
\hline LEV & $=$ & Leverage ratio, defined as total liabilities divided by total assets \\
\hline ROA & $=$ & Return on assets \\
\hline$\triangle \mathrm{ROA}$ & $=$ & Changes in return on assets \\
\hline SGROW & $=$ & Sales growth, i.e. (sales $\mathrm{t}$ - sales $\mathrm{t}-1$ )/sales $\mathrm{t}-1$ \\
\hline AGE & $=$ & Number of years since initial public offering \\
\hline LOSS & $=$ & $\begin{array}{l}\text { Dummy variable, } 1 \text { if the firm reports a loss in the current year, } 0 \\
\text { otherwise }\end{array}$ \\
\hline PRIORCGO & $=$ & $\begin{array}{l}\text { Dummy variable, } 1 \text { if the firm receive going concern opinion in } t-1,0 \\
\text { otherwise }\end{array}$ \\
\hline YEAR & $=$ & Year dummies \\
\hline INDUSTRY & $=$ & Industry dummies \\
\hline \multicolumn{3}{|l|}{ Equation (2) } \\
\hline TACCR & $=$ & $\begin{array}{l}\text { Total accruals, i.e. operating income minus cash flows from operating } \\
\text { activities }\end{array}$ \\
\hline TA & $=$ & Total assets \\
\hline SSA & $=$ & Net value of property, plant, and equipment \\
\hline SPPENT & $=$ & Changes in sales minus change in account receivable \\
\hline ROA & $=$ & Return on assets \\
\hline \multicolumn{3}{|c|}{ Equation (4), (5), (6) } \\
\hline CFO & $=$ & Cash flows from operating activities \\
\hline A & $=$ & Total assets \\
\hline S & $=$ & Sales \\
\hline$\Delta \mathrm{S}$ & $=$ & Changes in sales, i.e. sales $\mathrm{t}$ - sales t-1 \\
\hline PROD & $=$ & The sum of the cost of goods sold and changes in inventory \\
\hline DISEXP & $=$ & The sum of R\&D costs, promotion costs, and SG\&A \\
\hline ABCFO & $=$ & Abnormal cash flows from operating activities \\
\hline ABPROD & $=$ & Abnormal production cost \\
\hline ABDISEXP & $=$ & Abnormal discretionary expenses \\
\hline
\end{tabular}


Herusetya \& Stefani

The Association of Tax Aggressiveness on Accrual and Real Earnings Management

Table 2 Definition of Variables (cont'd)

\begin{tabular}{lll}
\hline \multicolumn{1}{c}{ Variables } & & Definition \\
\hline Equation 7 & $=$ & Tax shelter based on Wilson's (2009) tax shelter prediction model \\
SHELTER & $=\begin{array}{l}\text { Book-tax differences, i.e., (book income minus taxable } \\
\text { income)/lagged total assets }\end{array}$ \\
BTD & $=$ & Absolute value of discretionary accruals \\
IDAC| & $=$ & Leverage ratio, defined as total liabilities divided by total assets \\
LEV & $=$ & Natural logarithm of total assets \\
SIZE & $=$ & Return on assets \\
ROA & $=$ & Foreign income, given 1 if the firm report foreign income in the \\
FINC & $=$ financial statements, 0 otherwise \\
R\&D & $=$ Identification for firm I, year $t$ \\
i,t & $=$ Residual errors \\
e &
\end{tabular}

Managers engage in a combination of real transaction activities, including sales manipulation by giving discounts and more flexible time to pay off trade receivables so that sales may increase, to produce overproduction so that the cost of goods sold per unit decreases, and to postpone some of the discretionary expenses, such as research and development expenses, promotion expenses, etc., in order to achieve the desired earnings target (Roychowdhury, 2006). Following Kim and Park (2014), each real transaction at the individual level is calculated using Equations (4), (5), and (6). The cash flow of normal operating activities is a linear function of sales and changes in sales in the current period using Equation (4) as follows:

$\mathrm{CFO}_{\text {it }} / \mathrm{TA}_{\mathrm{it}-1}=\alpha_{0}+\alpha_{1}\left(1 / \mathrm{TA}_{\mathrm{it}-1}\right)+\beta_{1}\left(\mathrm{~S}_{\mathrm{it}} / \mathrm{TA}_{\mathrm{it}-1}\right)+\beta_{2}\left(\Delta \mathrm{S}_{\mathrm{it}} / \mathrm{TA}_{\mathrm{it}-1}\right)+\varepsilon_{\text {it }}$

The abnormal operating cash flow (ABCFO) is obtained from the actual value of CFO minus the estimated value of normal operating cash flow derived from the Equation (4), or we get from the value of residual errors of the Equation (4). The production activities as a linear function of production activities are calculated using the regression Equation (5) as follows:

$\mathrm{PROD}_{\mathrm{it}} / \mathrm{TA}_{\mathrm{it}-1}=\alpha_{0}+\alpha_{1}\left(1 / \mathrm{TA}_{\mathrm{it}-1}\right)+\beta_{1}\left(\mathrm{~S}_{\mathrm{it}} / \mathrm{TA}_{\mathrm{it}-1}\right)+\beta_{2}\left(\Delta \mathrm{S}_{\mathrm{it}} / \mathrm{TA}_{\mathrm{it}-1}\right)+\beta_{3}\left(\Delta \mathrm{S}_{\mathrm{it}-1} / \mathrm{TA}_{\mathrm{it}-1}\right)+\varepsilon_{\mathrm{it}}(5)$

The abnormal production (ABPROD) is obtained from the actual production (PROD) deducted by the value of the normal production estimated from the Equation (5), or it can be obtained from the residual error of Equation (5). Finally, discretionary expense (DISEXP) as a linear function of sales of the current period is calculated using the regression Equation (6) as follows:

DISEXP ${ }_{i t} / \mathrm{TA}_{\mathrm{it}-1}=\alpha_{0}+\alpha_{1}\left(1 / \mathrm{TA}_{\mathrm{it}-1}\right)+\beta_{1}\left(\mathrm{~S}_{\mathrm{it}-1} / \mathrm{TA}_{\mathrm{it}-1}\right)+\varepsilon_{\mathrm{it}}$

The value of abnormal discretionary expense (ABDISEXP) is obtained from the actual value of the operating expenses minus the estimated value of the normal operating 


\section{Herusetya \& Stefani \\ The Association of Tax Aggressiveness on Accrual and Real Earnings Management}

expense. It can be obtained from the residual error value of the Equation (6). The definition of all variables used in the Equations (3), (4), (5), and (6) can be seen in Table 2.

The value of abnormal operating cash flow (ABCFO) is predicted to be negative because the actual cash flow from operations is lower than the normal operating cash flows when managers manipulate sales that affect the future operating cash flows. The value of abnormal production costs is expected to be positive because actual production costs are higher than normal production costs indicate the existence of overproduction. The value of abnormal discretionary expense is predicted to be negative because the manager minimizes the discretionary expense. Following Chi et al. (2011), each value of $A B C F O, A B P R O D$, and ABDISEXP were standardized using the formula $(x-\mu) / \sigma$ for each year. REM is a measure of real transaction manipulation at an aggregate level, and it is predictive to be positive. It is a combination of the sum of the standardized values of abnormal discretionary expense (ABDISEXP), abnormal production costs (ABPROD), and abnormal operating cash flows (ABCFO), i.e., (ABPROD - ABCFO - ABDISEXP) (Chi et al., 2011; Roychowdhury, 2006; Kim and Park, 2014).

Tax Aggressiveness (TAXAGG)

Following prior studies, we use tax shelter as a proxy of tax aggressiveness (e.g., Zang et al., 2013; Kim et al. 2011). Graham and Tucker (2006) suggest that the tax shelter model was used by considering a more comprehensive set of company characteristics, such as foreign operations, book-tax differences, and aggressive financial reporting. Our study use Wilson's (2009) tax shelter prediction model implemented by Kim et al. (2011) as follows:

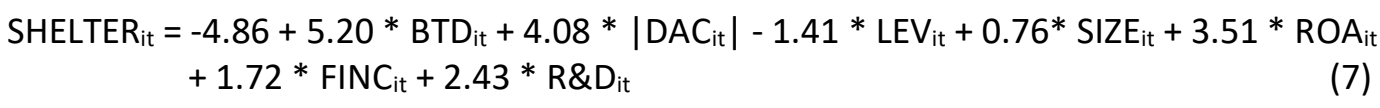

Following Kim and Park (2011), after we got the value of SHELTER in Equation (7), we rank all values from highest to lowest for each year and converted into decile. SHELTER_DES is a SHELTER value that has a range from 0 to 1 . The closer the value to 1 , it means that the company has a higher tendency of tax aggressiveness, and vice versa. TAXAGG is the value of SHELTER_DES for each related company. The definition of variables in Equation (7) can be seen in Table 2.

\section{Control Variables}

Following previous studies (e.g., Gul et al., 2009; Defond and Zhang, 2014; Becker et al., 1998; Gaver and Utke, 2019; Balsam et al., 2003; Frank et al., 2009), we use several control variables in Equation (1) for Model 1 and Equation (3) for Model 2 that can influence the dependent variables (ABSDAC and REM), i.e., return on assets (ROA), change in return on assets ( $\triangle R O A)$, company size (SIZE), leverage (LEV), sales growth (GROWTH), company's age (AGE), loss (LOSS), prior going concern opinion (PRIORGCO). In Model 1 and Model 2, use also use real earnings management (REM) and accrual 


\section{Herusetya \& Stefani \\ The Association of Tax Aggressiveness on Accrual and Real Earnings Management}

earnings management (ABSDAC) as control variables, because managers use these instruments as a combination to achieve earnings targets (Kim and Park, 2014; Zang, 2012; Cohen and Zarowin, 2010). We use dummy variables for industry (INDUSTRY) and YEAR to eliminate the fixed effects of years and industries (Gul et al., 2009).

\section{Result and Discussion}

\section{Descriptive Statistics and Correlation Analysis}

Table 3 presents the descriptive statistics for all research variables used in Model 1 (Eq. 1) and Model 2 (Eq. 3). All continuous data are winsorized using mean \pm two standard deviations to avoid data that are outliers. Discretionary accrual (ABSDAC) has a positive and mean value of 0.066 , It indicates that on average the firm-year observations engage in accrual-based earnings management (ABSDAC) with the magnitude value of 6.64 percent of total assets, with a minimum value of 0.02 percent and a maximum value of 37.36 percent. The mean of real transaction earnings management at the aggregate level (REM) is positive with the amount of 0.048 or 4.78 percent of total assets, with a minimum value of $-4,371$ and a maximum value of 4,371 . The mean of real transaction earnings management (REM) at the individual level, i.e., abnormal CFO (ABCFO), abnormal production costs (ABPROD), and abnormal discretionary expense (ABDISEXP), each of which is $-0.044,0.165$ and -0.132 . These results indicate that, on average, the firm-year observations perform real transaction activities in abnormal operating cash flows (ABCFO), overproduction costs (ABPROD), and abnormal discretionary expense (ABDISEXP), each at 4.36 percent, 16.54 percent, and 13.17 percent of total assets. The mean tax aggressiveness (TAXAGG) using a tax shelter is 0.650 , with a minimum value of 0.301 and a maximum of 1.000 .

Table 3 Descriptive Statistics

\begin{tabular}{lrrrr}
\multicolumn{1}{c}{ Variables } & Mean & Standard Deviation & Minimum & Maximum \\
\hline ABSDAC & 0.066 & 0.071 & 0.000 & 0.374 \\
REM & 0.048 & 2.007 & -4.371 & 4.371 \\
ABCFO & -0.044 & 0.131 & -0.495 & 0.422 \\
ABPROD & 0.165 & 0.364 & -2.333 & 1.9938 \\
ABDISEXP & -0.132 & 0.148 & -0.382 & 0.294 \\
TAXAGG & 0.650 & 0.142 & 0.301 & 1.000 \\
SIZE & 14.361 & 1.620 & 10.503 & 19.505 \\
LEV & 0.464 & 0.268 & 0.008 & 1.342 \\
ROA & 0.059 & 0.104 & -0.214 & 0.356 \\
AROA & -0.045 & 1.832 & -7.319 & 9.522 \\
SGROW & 0.078 & 0.318 & -1.000 & 2.801 \\
AGE & 20.124 & 7.517 & 1.000 & 36.000 \\
LOSS & 0.236 & 0.425 & 0.000 & 1.000 \\
PRIORGCO & 0.028 & 1.165 & 0.000 & 1.000 \\
All variables are described in Table 2. & & & \\
\hline
\end{tabular}


Pairwise Correlations between variables used in this study can be seen in Table 4 . The correlation coefficient of tax aggressiveness (TAXAGG) on accrual earnings management (ABSDAC) is 0.004 , not significant at 0.10 . The TAXAGG coefficient has a negative correlation with REM, i.e., -0.309 , significant at 0.01 level, and has a correlation coefficient of $0.351,-0.141$ and 0.191 , respectively for abnormal CFO (ABCFO), abnormal production (ABPROD), and abnormal discretionary expense (ABDISEXP), each with a significance level of 0.01. Tax aggressiveness (TAXAGG) is positively related to larger companies (SIZE), high return on assets (ROA), high growth rates (SGROW), company age (AGE), each with a significance level of 0.01 , and negatively related to companies that have leverage (LEV), LOSS and PRIORGCO, each with a significance level of 0.01 . Larger companies (SIZE) have a negative correlation with ABSDAC, while LEV, ROA, and DROA positively correlate with ABSDAC. REM and ABSDAC have a positive correlation of 0.089 , significant at 0.05 .

Table 4 Variable Correlations

\begin{tabular}{|c|c|c|c|c|c|c|c|}
\hline Variables & 1 & 2 & 3 & 4 & 5 & 6 & 7 \\
\hline ABSDAC & 1.000 & & & & & & \\
\hline REM & $0.089^{* *}$ & 1.000 & & & & & \\
\hline ABCFO & -0.064 & $-0.650 * * *$ & 1.000 & & & & \\
\hline ABPROD & $0.087 * *$ & $0.752^{* * *}$ & $-0.253 * * *$ & 1.000 & & & \\
\hline ABDISEXP & -0.030 & $-0.752 * * *$ & $0.201 * * *$ & $-0.434 * * *$ & 1.000 & & \\
\hline TAXAGG & 0.004 & $-0.309 * * *$ & $0.351 * * *$ & $-0.141 * * *$ & $0.191^{* * *}$ & 1.000 & \\
\hline SIZE & $\begin{array}{l}- \\
0.183^{* * *}\end{array}$ & $-0.111^{* *}$ & $0.142^{* * *}$ & $-0.085^{*}$ & 0.019 & $0.752^{* * *}$ & 1.000 \\
\hline LEV & $0.123 * * *$ & $0.254^{* * *}$ & $-0.210 * * *$ & $0.171 * * *$ & $-0.121 * * *$ & $-0.140 * * *$ & -0.001 \\
\hline ROA & $0.073^{*}$ & $-0.534 * * *$ & $0.528^{* * *}$ & $-0.312^{* * *}$ & $0.342 * * *$ & $0.480 * * *$ & $0.145^{* * *}$ \\
\hline$\triangle \mathrm{ROA}$ & $0.086^{*}$ & -0.044 & 0.073 & 0.005 & 0.011 & 0.013 & -0.026 \\
\hline SGROW & -0.012 & -0.061 & -0.072 & $-0.107^{* *}$ & $0.109^{* *}$ & $0.117^{* * *}$ & 0.048 \\
\hline AGE & 0.200 & $-0.160 * * *$ & $0.234 * * *$ & -0.032 & $0.097^{* *}$ & $0.353^{* * *}$ & $0.139 * * *$ \\
\hline LOSS & 0.070 & $0.312^{* * *}$ & $-0.243^{* * *}$ & $0.172^{* * *}$ & $-0.243^{* * *}$ & $-0.344^{* * *}$ & $\begin{array}{l}- \\
0.112^{* * *}\end{array}$ \\
\hline PRIORGCO & 0.046 & $0.164^{* * *}$ & -0.070 & $0.113^{* * *}$ & $-0.154 * * *$ & $-0.168 * * *$ & -0.066 \\
\hline \multicolumn{8}{|c|}{$* * *, * *, *$ Indicate significance at the $0.01,0.05$ and 0.10 levels, respectively. All variables are described in Table 2.} \\
\hline Variables & 8 & 9 & 10 & 11 & 12 & 13 & 14 \\
\hline LEV & 1.000 & & & & & & \\
\hline ROA & $\begin{array}{l}- \\
0.372^{* * *}\end{array}$ & 1.000 & & & & & \\
\hline$\triangle \mathrm{ROA}$ & $0.139 * * *$ & $0.139 * * *$ & 1.000 & & & & \\
\hline SGROW & $0.149 * * *$ & $0.149 * * *$ & $0.138^{* * *}$ & 1.000 & & & \\
\hline AGE & $0.230 * * *$ & $0.230 * * *$ & 0.042 & -0.021 & 1.000 & & \\
\hline LOSS & $\begin{array}{l}- \\
0.584^{* * *}\end{array}$ & $-0.584 * * *$ & $-0.078^{*}$ & $-0.140 * * *$ & $-0.30 * * *$ & 1.000 & \\
\hline PRIORGCO & $\begin{array}{l}- \\
0.191^{* * *}\end{array}$ & $-0.191 * * *$ & 0.001 & 0.009 & -0.025 & $0.277^{* * *}$ & 1.000 \\
\hline
\end{tabular}

Regression Results of Hypothesis $1(\mathrm{H} 1)$

Table 5 reports the results of the $\mathrm{H} 1$ hypothesis. Model 1 (Eq. 1 ) has F-value of 8.73 $(p<0.001)$ with a value of R-squared 0.1515 and adjusted R-squared 0.1342 . Model 1 has good model specifications with all independent variables having the ability to explain 


\author{
Herusetya \& Stefani \\ The Association of Tax Aggressiveness on Accrual and Real Earnings Management
}

the accrual earnings management (ABSDAC) as a dependent variable of around 13.42 percent. This specification model meets the initial tests in the classic assumption test. The normality test results using the Shapiro-Wilk Normality Test have $p<0.001$, so we use a Box-Cox treatment for the ABSDAC variable to have zero skewness. Heteroscedasticity test results using the Breusch-Pagan/Cook-Weisberg test do not contain heteroscedasticity problems (Prob> chi2 $=0.2789$ ). The average VIF value of all variables is 1.82 , with the VIF value of TAXAGG is $3.83<10$, so it does not contain a multicollinearity.

The tax aggressiveness variable (TAXAGG) in Table 5 has a positive coefficient of 0.208 , significant at 0.01 ( $\mathrm{t}$-test $=5.25, \mathrm{p}<0.001$ ). Our test shows that tax aggressiveness (TAXAGG) has a positive association with accrual-based earnings management (ABSDAC), after controlling for variables that influence the ABSDAC, including REM. Our findings support the $\mathrm{H} 1$ hypothesis's prediction, and consistent with the previous studies, for example, Frank et al. (2009). Thus the H1 hypothesis is accepted. These findings give an interpretation that managers engage in tax aggressiveness through tax shelter activities; they also have a higher tendency to conduct accrual-based earnings management. Our results are consistent with the previous studies suggesting that managers do not need to trade-off between aggressive tax reporting decisions and aggressive financial reporting decisions (Frank et al., 2009).

The results of control variables tests in Table 5, show some control variables significant following the initial predictions. The SIZE variable is negatively associated with ABSDAC at 0.01 , indicating that a larger company (SIZE) has a negative association with accrual earnings management (ABSDAC). Leverage (LEV), return on assets (ROA), and companies that experience losses (LOSS) each have a positive association with ABSDAC, significant at 0.01 , respectively. Companies that involve in real transaction earnings management (REM) tend to be also involved in accrual earnings management (ABSDAC), as evidenced by the positive relationship between REM and ABSDAC, significant at 0.10 (Chan et al., 2015, Zang, 2012; Cohen and Zarowin, 2010).

Regression Results of Hypothesis 2 (H2)

Table 5 explains the results of the $\mathrm{H} 2$ hypothesis testing. Model 2 in Equation 3 has a model specification with an F-value of 22.34, with R-squared and adjusted R-squared, respectively 0.3136 and 0.2996 . This specification model meets the initial tests in the classic assumption test. The results of the normality test using the Shapiro-Wilk Normality Test are $p<0.001$, so we use a Box-Cox treatment for the REM variable to have zero skewness. Heteroscedasticity test results using the Breusch-Pagan/CookWeisberg test do not contain heteroscedasticity problems (Prob> chi2 $=0.4976$ ). The average VIF value of all variables is 1.78 , with the VIF value of TAXAGG is $4.00<10$, so it does not contain an indication of multicollinearity. 
Herusetya \& Stefani

The Association of Tax Aggressiveness on Accrual and Real Earnings Management

Table 5 Regression Results of $\mathrm{H} 1$ and $\mathrm{H} 2$ Hypothesis

\begin{tabular}{|c|c|c|c|c|c|c|c|}
\hline \multirow[t]{3}{*}{ Independent Variables } & \multirow{3}{*}{$\begin{array}{l}\text { Dependent } \\
\text { Variable } \\
\text { Predicted } \\
\text { Sign }\end{array}$} & \multicolumn{3}{|c|}{ ABSDAC } & \multicolumn{3}{|c|}{ REM } \\
\hline & & \multicolumn{3}{|c|}{ Model 1 (Eq. 1) } & \multicolumn{3}{|c|}{ Model 2 (Eq. 3) } \\
\hline & & Coefficient & t-test & Prob. & Coefficient & t-test & Prob. \\
\hline TAXAGG & + & $0.208^{* * *}$ & 5.25 & 0.000 & $-2.325^{* *}$ & -2.25 & 0.025 \\
\hline SIZE & ? & $-0.021 * * *$ & -6.96 & 0.000 & 0.133 & 1.64 & 0.101 \\
\hline LEV & ? & $0.039 * * *$ & 3.06 & 0.002 & 0.248 & 0.76 & 0.448 \\
\hline ROA & ? & $0127 * * *$ & 2.85 & 0.005 & $-9.725 * * *$ & -9.24 & 0.000 \\
\hline$\triangle \mathrm{ROA}$ & ? & 0.003 & 1.57 & 0.118 & 0.011 & 0.25 & 0.803 \\
\hline SGROW & - & -0.010 & -1.09 & 0.276 & 0.128 & 0.53 & 0.598 \\
\hline AGE & - & -0.001 & -1.27 & 0.206 & 0.008 & 0.73 & 0.467 \\
\hline LOSS & ? & $0.024 * * *$ & 2.68 & 0.008 & -0.248 & -1.08 & 0.279 \\
\hline PRIORGCO & - & 0.000 & 0.01 & 0.990 & 0.534 & 1.08 & 0.283 \\
\hline REM & + & $0.006 * * *$ & 3.53 & 0.000 & & & \\
\hline ABSDAC & + & & & & $4.010^{* * *}$ & 3.53 & 0.000 \\
\hline INDUSTRY & ? & Yes & & & Yes & & \\
\hline YEAR & ? & Yes & & & Yes & & \\
\hline CONSTANT & ? & 0.214 & 7.10 & 0.000 & -0.272 & -0.34 & 0.735 \\
\hline F-value & & 8.73 & & & 22.34 & & \\
\hline Prob. $>\mathrm{F}$ & & $p<0.000$ & & & $p<0.000$ & & \\
\hline R-squared & & 0.1515 & & & 0.3136 & & \\
\hline Adjusted R-Squared & & 0.1342 & & & 0.2996 & & \\
\hline $\mathrm{N}$ & & 500 & & & 500 & & \\
\hline
\end{tabular}

The TAXAGG variable has a negative coefficient of -2.325 , significant at 0.05 (t-test $=$ $2.25, \mathrm{p}=0.025$ ). The results of this study differ from $\mathrm{H} 2$ hypothesis predictions, where tax aggressiveness (TAXAGG) has a negative association with real transaction earnings management (REM) at the aggregate level, after controlling for variables that also influence REM, including the accrual earnings management (ABSDAC). This finding gives an interpretation that companies that engage in tax aggressiveness through tax shelters tend to reduce real transaction activities at the aggregate level (REM), by combining the real transaction activities that encourage sales manipulation, overproduction, and reducing discretionary operating expenses. The $\mathrm{H} 2$ hypothesis is thus rejected.

Some alternative explanations regarding these findings are as follows. First, managers can engage in earnings management mechanisms by combining discretionary accruals and real transaction earnings management to achieve short-term earnings targets while simultaneously achieving tax reporting goals (e.g., Chan et al., 2015; Zang, 2012; Cohen and Zarowin, 2010). Second, tax aggressiveness contains high tax uncertainties and reduces cash taxes (Dyreng et al., 2019); thus, managers tend to reduce real transaction activities that impact decreasing operational cash flows so that real transaction earnings management at the aggregate level is reduced.

Another alternative explanation is that Wilson's (2009) tax shelter prediction model contains accrual discretionary and book-tax difference (BTD), where "book-tax differences are incrementally useful to accrual in identifying earnings management, fraud, and restatements (Gaver and Utke, 2019, p. 117). Wilson (2009) found a positive relationship between book-tax differences in the likelihood of companies involved in tax shelter activities. This difference in accounting and tax earnings is increasingly a signal of aggressive tax reporting, so managers get involved in a combination of accrual and real 


\section{Herusetya \& Stefani}

The Association of Tax Aggressiveness on Accrual and Real Earnings Management

transaction earnings management in carrying out tax shelter activities to achieve the objectives of tax reporting and aggressive financial reporting in the same reporting period.

The testing results of control variables are mostly insignificant, except for ROA and ABSDAC. Return on assets is negatively related to REM at the 0.01 level. ABSDAC is positively related to REM at 0.01 , consistent with initial predictions that managers can use accrual and real transactions as a combination to achieve earnings targets (e.g., Chan et al., 2015; Zang, 2012; Cohen and Zarowin, 2010).

\section{Additional Tests}

Additional tests is conducted to examine the effect of tax aggressiveness on real transaction earnings management at the individual level, which includes abnormal CFO (ABCFO), abnormal production (ABPROD), and abnormal discretionary expense ( $A B D I S E X P)$. The results of additional tests for Model 2 using the dependent variables ABCFO, ABPROD, and ABSDISEXP can be seen in Table 6.

Table 6 Additional Test Results of $\mathrm{H} 2$ Hypothesis

\begin{tabular}{|c|c|c|c|c|c|c|c|c|c|c|}
\hline \multirow{4}{*}{$\begin{array}{l}\text { Independent } \\
\text { Variables }\end{array}$} & Dep. & \multicolumn{3}{|c|}{ ABCFO } & \multicolumn{3}{|c|}{ ABPROD } & \multicolumn{3}{|c|}{ ABDISEXP } \\
\hline & \multicolumn{10}{|l|}{ Variable } \\
\hline & \multirow{2}{*}{$\begin{array}{l}\text { Pred. } \\
\text { Sign }\end{array}$} & \multicolumn{3}{|c|}{ Model 2 (Eq. 2) } & \multicolumn{3}{|c|}{ Model 2 (Eq. 2) } & \multicolumn{3}{|c|}{ Model 2 (Eq. 2) } \\
\hline & & Coeff. & t-test & Prob. & Coeff. & t-test & Prob. & Coeff. & $\begin{array}{c}\mathrm{t}- \\
\text { test }\end{array}$ & Prob. \\
\hline TAXAGG & + & $0.231 * * *$ & 3.49 & 0.001 & 0.176 & 0.83 & 0.407 & $0.180^{* *}$ & 2.11 & 0.035 \\
\hline SIZE & $?$ & $-0.010 * *$ & -2.02 & 0.044 & -0.017 & -1.03 & 0.306 & $-0.016^{* *}$ & $\begin{array}{r}- \\
2.46\end{array}$ & 0.014 \\
\hline LEV & + & -0.010 & -0.46 & 0.645 & 0.063 & 0.94 & 0.346 & 0.030 & 1.13 & 0.258 \\
\hline ROA & - & $0.656^{* * *}$ & 9.73 & 0.000 & $-1.265^{* * *}$ & -5.86 & 0.000 & $0.380 * * *$ & 4.61 & 0.000 \\
\hline$\triangle R O A$ & $?$ & 0.003 & 0.99 & 0.323 & 0.007 & 0.85 & 0.398 & -0.003 & $\begin{array}{r}- \\
0.88\end{array}$ & 0.379 \\
\hline SGROW & + & $-0.068 * * *$ & -4.36 & 0.000 & $-0.082^{*}$ & -1.66 & 0.098 & 0.026 & 1.30 & 0.195 \\
\hline AGE & - & 0.000 & 0.63 & 0.526 & 0.003 & 1.26 & 0.208 & -0.000 & $\begin{array}{r}- \\
0.46\end{array}$ & 0.642 \\
\hline LOSS & - & $0.037 * *$ & 2.50 & 0.013 & -0.049 & -1.05 & 0.294 & -0.009 & 0.49 & 0.627 \\
\hline PRIORGCO & + & 0.036 & 1.13 & 0.259 & 0.108 & 1.06 & 0.290 & $-0.082^{* *}$ & 2.01 & 0.045 \\
\hline ABSDAC & + & $-0.258 * * *$ & -3.55 & 0.000 & $0.457^{* *}$ & 1.96 & 0.050 & $-0.169 *$ & $\begin{array}{r}- \\
1.81\end{array}$ & 0.081 \\
\hline INDUSTRY & $?$ & Yes & & & Yes & & & Yes & & \\
\hline YEAR & $?$ & Yes & & & Yes & & & Yes & & \\
\hline CONSTANT & $?$ & -0.075 & -1.46 & 0.146 & 0.267 & 1.62 & 0.106 & -0.031 & 0.46 & 0.644 \\
\hline F-value & & 25.83 & & & 7.02 & & & 8.35 & & \\
\hline Prob. $>\mathrm{F}$ & & $p<0.000$ & & & $p<0.000$ & & & $p<0.000$ & & \\
\hline R-squared & & 0.3457 & & & 0.1255 & & & 0.1458 & & \\
\hline Adjusted R-Squared & & 0.3323 & & & 0.1076 & & & 0.1284 & & \\
\hline $\mathbf{N}$ & & 500 & & & 500 & & & 500 & & \\
\hline
\end{tabular}

TAXAGG variable in Table 6 has a coefficient of 0.231 , positive and significant at the 0.01 level ( $t$-test $=3.49, p<0.001$ ), consistent with the previous main findings of Model 2 measured at the aggregate level (REM). This finding indicates that tax aggressiveness 


\author{
Herusetya \& Stefani \\ The Association of Tax Aggressiveness on Accrual and Real Earnings Management
}

(TAXAGG) is negatively related to abnormal CFO (ABCFO), which indicates that the higher the tax aggressiveness using tax shelter activities, the company tends to reduce real transactions by decreasing sales manipulation that has a positive impact on cash flows from operations.

The second additional test using over production activities (ABPROD) can be seen in Table 6. The test results show that the TAXAGG coefficient is not significant at 0.10 (ttest $=0.83, p=0.407)$. In other words, tax aggressiveness has no association with overproduction activities. In Table 6, additional testing using ABDISEXP, shows that the TAXAGG coefficient is 0.180 , positive and significant at 0.05 ( $t$-test $=2.11, p=0.035$ ). This finding supports the main result in Model 2, where tax shelter activities have a negative association with real transaction activities by reducing the negative value of abnormal discretionary expenses (ABDISEXP).

Overall, these additional tests support the main results of the $\mathrm{H} 2$ hypothesis in Model 2, where managers perform a combination of real transactions at the individual levels by reducing sales manipulation by which might affect a positive operating cash flows and by postponing the discretionary operating expenses. Managers make combinations at the individual level of real transactions and discretionary accruals as earnings management tools to achieve the objectives of reporting tax aggressiveness and earnings target.

\title{
Conclusion
}

This study investigates the association of tax aggressiveness and earnings management behavior using accruals and real transactions. This study sample consists of 500 firmyear observations from the manufacturing industry listed on the Indonesia Stock Exchange (IDX) with an observation period of 2013 -2017. We find evidence of a positive association between the tax aggressiveness using tax shelter activities and the aggressive financial reporting on a discretionary accrual basis. Our study finds evidence that is contrary to our hypothesis, that the tax aggressiveness is negatively associated with the real transaction earnings management at the aggregate level. An alternative explanation for this finding is that, in order to meet the objectives of tax reporting and aggressive financial reporting in the same period, managers make a combination of tools of accrual and real transaction earnings management. In our additional tests, we also found consistent results with our main findings, i.e., the tax aggressiveness using tax shelters activities negatively associated with real transaction activities at the individual level. This study finds that each tax aggressiveness is negatively associated with decreasing abnormal operating cash flows and abnormal discretionary expense, but found no evidence for the abnormal production.

This study's findings have implications for both the tax authorities and capital market players, i.e., that managers can achieve aggressive tax reporting and financial reporting decisions in the same period without requiring a trade-off between the two. Our study has several limitations. First, this study measures tax aggressiveness using Wilson's 


\author{
Herusetya \& Stefani \\ The Association of Tax Aggressiveness on Accrual and Real Earnings Management
}

(2009) tax shelter prediction model as the highest level of tax aggressiveness. Lisowsky et al. (2013) suggest that tax aggressiveness can be carried out from the extreme to the lowest levels i.e., tax shelter, discretionary permanent book-tax difference (DTAX), permanent book-tax difference (PBTD), book-tax differences (BTD), to the cash effective tax rates (CETR). Second, our study used accrual-based earnings management and real transactions to achieve aggressive financial reporting decisions but did not consider the specific earnings targets related to aggressive tax reporting. Previous studies documented that earnings management tools can be used to achieve specific earnings targets, especially in the short term as financial reporting decisions (e.g., Chan et al., 2015; Zang, 2012; Beyer et al., 2018; Gul et al., 2009; Frank and Rego, 2006). Due to our limitations, further studies can investigate the association of aggressive tax reporting using the different level of tax aggressiveness and aggressive financial reporting to achieve specific earnings targets..

\title{
References
}

Astutik, D., \& Venusita, V. (2020). The Influence of CEO's Demographic Characteristics on Tax Aggressiveness in Family Firm. Jurnal Akuntansi dan Keuangan, 22(1), 1-9. https://doi.org/10.9744/jak.22.1.1-9

Badertscher, B., Phillips, J., Pincus, M., \& Rego, S. (2009). Earnings Management Strategies: To Conform or not to Conform? The Accounting Review, 84(2), 63-98.

https://doi.org/10.2308/accr.2009.84.1.63

Balsam, S., Khrisnan, J., \& Yang, J.S. (2003). Auditor Industry Specialization and Earnings Quality. Auditing: A Journal of Practice \& Theory, 22(2), 71-97. https://doi.org/10.2308/aud.2003.22.2.71

Becker, C.L., DeFond, J.J., \& Subramanyam, K.R. (1998). The Effect of Audit Quality on Earnings Management. Contemporary Accounting Research, 15(1), 1-24. https://doi.org/10.1111/j.1911-3846.1998.tb00547.x

Beyer, B.D., Nabar, S.M., \& Rapley, E.T. (2018). Real Earnings Management by Benchmark Beating Firms: Implication for Future Operating Profit. Accounting Horizons, 32(4), 5984. https://doi.org/10.2308/acch-52167

Chan, L.H., Chen, K.C.W., \& Chen, T.Y., \& Yu, Y. (2015). Substitution between Real and Accruals- Based Earnings Management after Voluntary Adoption of Compensation Clawback Provisions. The Accounting Review, 90(1), 147-174. https://doi.org/10.2308/accr-50862

Chi, W., Lisic, L. L., \& Pevzner, M. (2011). Is Enhanced Audit Quality Associated with Greate Real Earnings Management? Accounting Horizons, 25(2), 315-335. https://doi.org/10.2308/acch-50082

Cohen, D. A. \& Zarowin, P. (2010). Accrual Based and Real Earnings Management Activities Around Seasoned Equity Offerings. Journal of Accounting and Economics, 50(1), 2-19. https://doi.org/10.1016/i.jacceco.2010.01.002

Dhaliwal, D., Gleason, C., Mills, L. (2004). Last Chance Earnings Management: Using the Tax Expense to Meet Analysts' Forecasts. Contemporary Accounting Research, 21(2), 431459. https://doi.org/10.1506/tfvv-uyt1-nnyt-1yfh

DeFond, M. \& Zhang, J. (2014). A Review of Archival Auditing Research. Journal of Accounting and Economics, 58(1), 275-326. https://doi.org/10.1016/j.jacceco.2014.09.002 
Dechow, P. M., Hutton, A. P., Kim, J. H., \& Sloan, R. G. (2012). Detecting Earnings Management: A New Approach. Journal of Accounting Research, 50(2), 275-334. https://doi.org/10.1111/j.1475-679x.2012.00449.x

Desai, M. A. \& Dharmapala, D. (2006). Corporate Tax Avoidance and High-Powered Incentives. Journal of Financial Economics, 79(1), 145-179. https://doi.org/10.1016/i.jfineco.2005.02.002

Desai, M., A. \& Dharmapala, D. (2009). Earnings management, Coprporate Tax Shelters, and Book-Tax Alignment. National Tax Joumal, 62(1), 169-186. https://doi.org/10.17310/nti.2009.1.08

Dyreng, S.D., Hanlon, M. \& Maydew, E.L. (2019). When Tax Avoidance Result in Tax Uncertainty? The Accounting Review, 94(2), 179-203. https://doi.org/10.2308/accr$\underline{52198}$

Frank, M.M, \& Rego, S. (2006). Do Managers Use Valuation Allowance Account to Manage Earnings around Certain Earnings Targets? The Journal of the American Taxation Association, 28(1), 43-65. https://doi.org/10.2308/jata.2006.28.1.43

Frank, M. M., Lynch, L. J., \& Rego, S. O. (2009). Tax Reporting Aggressiveness and Its Relation to Aggressive Financial Reporting. The Accounting Review, 84(2), 467-496. https://doi.org/10.2308/accr.2009.84.2.467

Gaver, J.J \& Utke, S. (2019). Audit Quality and Specialist Tenure. The Accounting Review 94(3), 113-147. https://doi.org/10.2308/accr-52206

Geraldina, I. (2013). Preferensi Manajemen Laba Akrual atau Manajemen Laba Riil dalam Aktivitas Tax Shelter. Jurnal Akuntansi dan Kenangan Indonesia, 10(2), 206-224. https://doi.org/10.21002/jaki.2013.11

Graham, J. \& Tucker, A. (2006). Tax Shelter and Corporate Debt Policy. Journal of Financial Economics, 81(1), 563-594. https://doi.org/10.1016/j.jfineco.2005.09.002

Graham, J., Harvey, C., Rajgopal, S. (2005). The Economic Implication of Corporate Financial Reporting. Journal of Accounting and Economics, 40(1/3), 3-73. https://doi.org/10.1016/i.jacceco.2005.01.002

Gul, F.A., Fung, S.Y.K., \& Jaggi, B. (2009). Earnings quality: Some evidence on the role of auditor tenure and auditors'industry expertise. Journal of Accounting and Economics, 49(1), 265- 287. https://doi.org/10.1016/i.jacceco.2009.03.001

Hanlon, M., Laplante, S. \& Shevlin, T. (2005). Evidence on the Possible Information Loss of Conforming Book Income and Taxable Income. Journal of Law \& Economics, 48(2), 407-442. https://doi.org/10.1086/497525

Hanlon, M. \& Heitzman, S. (2010). A Review of Tax Research. Journal of Accounting and Economics, 50(1), 127-178. https://doi.org/10.1016/i.jacceco.2010.09.002

Hidayati, W., \& Diyanty, V. (2018). Pengaruh Moderasi Koneksi Politik terhadap Kepemilikan Keluarga dan Agresivitas Pajak. Jurnal Akuntansi dan Auditing Indonesia, 22(1), 46-60. https://doi.org/10.20885/jaai.vol22.iss1.art5

Jones, J. (1991). Earnings Management During Import Relief Investigations. Journal of Accounting Research, 29(2), 193-228. https:// doi.org/10.2307/2491047

Kim, J. B., Li, Y., \& Zhang, L. (2011). Corporate Tax Avoidance and Stock Price Crash Risk: Firm-Level Analysis. Joumal of Financial Economics, 100(1), 639-662. https://doi.org/10.1016/i.jfineco.2010.07.007

Kim, Y. \& Park, M. S. (2014). Real Activities Manipulation and Auditors' Client-Retention Decisions. The Accounting Review, 89(1), 367-401. https://doi.org/10.2308/accr-50586

Kothari, S. P., Leone, A., \& Wasley, C. E. (2005). Performance Matched Discretionary Accrual Measures. Journal of Accounting and Economics, 39(1), 163-197. https://doi.org/10.1016/j.jacceco.2004.11.002 
Kothari, S. P., Mizik, N., \& Roychowdhury, S. (2016). Managing for the Moment: The Role of Earnings Management via Real Activities versus Accruals in SEO Valuation. The Accounting Review, 91(2), 559-586. https://doi.org/10.2308/accr-51153

Lennox, C., Lisowsky, P., \& Pittman, J. (2013). Tax Aggressiveness and Accounting Fraud. Journal of Accounting Research, 51(4), 739-778. https://doi.org/10.1111/joar.12002

Lisowsky, P., Robinson, \& L., Schmidt, A. 2013. Do Publicly Disclosed Tax Reserved Tell Us about Privately Disclosed Tax Shelter Activity? Journal of Accounting Research, 51(3), 583-629. https://doi.org/10.1111/joar.12003

Maraya, A.D., \& Yendrawati, R. (2016). Pengaruh Corporate Governance dan Corporate Social Responsibility Disclosure terhadap Tax Avoidance: Studi Empiris pada Perusahaan Tambang Dan CPO. Jurnal Akuntansi dan Auditing Indonesia, 20(2), 147159. https://doi.org/10.20885/jaai.vol20.iss2.art7

Octavia, \& Martani, D. (2013). Tingkat Pengungkapan dan Penggunaan Derivatif Keuangan dalam Aktivitas Penghindaran Pajak. Jurnal Akuntansi dan Kenangan Indonesia, 10(2), 129-146. https://doi.org/10.21002/jaki.2013.07

Rego, S. O. \& Wilson, R. J. (2012). Equity Risk Incentives and Corporate Tax Aggressiveness. Journal of Accounting Research, 50(3), 775-810. https://doi.org/10.1111/j.1475-679x.2012.00438.x

Roychowdhury, S. (2006). Earnings Management through Real Activities Manipulation. Journal of Accounting and Economics 42(1), 335-370. https://doi.org/10.1016/i.jacceco.2006.01.002

Sandy, S., \& Lukviarman, N. (2015). Pengaruh Corporate Governance terhadap Tax Avoidance: Studi Empiris pada Perusahaan Manufaktur. Jurnal Akuntansi dan Auditing Indonesia, 19(2), 85-98. https://doi.org/10.20885/jaai.vol19.iss2.art1

Shackelford., D., \& Shevlin, T. (2001). Empirical Tax Research in Accounting. Journal of Accounting and Economics, 31(1-3), 321-387. Retrieved from https://www.sciencedirect.com/journal/journal-of-accounting-andeconomics/vol/31/issue/1

Shevlin, T. J. (2002). Symposium on Corporate Tax Shelters, Part II: Commentary: Corporate Tax Shelters and Book Tax Differences. New York University Tax Law Review, 55(3), 427-433.

Surahman, A. \& Firmansyah, A. (2017). Effect of earnings management through accountings deviation, activities profit riil and acrual to tax aggressivity. Fundamental Management Journal, 2(2), 10-28. https://doi.org/10.33541/fjm.v2i2.517

Wilson, R. J. (2009). An Examination of Corporate Tax Shelter Participants. The Accounting Review, 84(3), 969-999. https://doi.org/10.2308/accr.2009.84.3.969

Zang, A. Y. (2012). Evidence on the Trade-Off between Real Activities Manipulation and Accrual-Based Earnings Management. The Accounting Review, 87(2), 675-703. https://doi.org/10.2308/accr-10196

Zang, Y., Goh, B. E., Lim, C.Y., \& Shevlin, T. (2013). Tax Aggressiveness and Auditor Resignation. Korean Accounting Association Annual Meeting. Research Collection School of Accountancy. Retrieved from https://ink.library.smu.edu.sg/soa research/1126 